\title{
Targeting nitric oxide production in microglia with novel imidazodiazepines for non-sedative pain treatment
}

Amanda N. Nieman ${ }^{\mathrm{a}}$, Guanguan Li ${ }^{\mathrm{b}}$, Nicolas M. Zahn ${ }^{\mathrm{a}}$, Md Yeunus Mian ${ }^{\mathrm{a}}$, Brandon N. Mikulskyc, Dylan A. Hoffman ${ }^{\mathrm{a}}$, Taylor M. Wilcox ${ }^{\mathrm{a}}$, Alexander S. Kehoe ${ }^{\mathrm{a}}$, Ian W. Luecke ${ }^{\mathrm{a}}$, Michael M. Poe ${ }^{\mathrm{d}}$, David Alvarez-Carbonell ${ }^{\mathrm{e}}$, James M. Cook ${ }^{\mathrm{a}}$, Douglas C. Stafford ${ }^{\mathrm{a}, \mathrm{c}}$ and Leggy

$$
\text { A. Arnold }{ }^{\mathrm{a}, \mathrm{c}, *}
$$

a Department of Chemistry and Biochemistry and the Milwaukee Institute for Drug Discovery, University of Wisconsin-Milwaukee, Milwaukee, Wisconsin 53201, United States

${ }^{\mathrm{b}}$ Shenzhen Grubbs Institute and Department of Chemistry, Shenzhen Key Laboratory of Small Molecule Drug Discovery and Synthesis, Southern University of Science and Technology, Shenzhen, Guangdong 518055, China

'Pantherics Incorporated, La Jolla, California 92037, United States

${ }^{\mathrm{d}}$ Department of Chemistry, Western Michigan University, Kalamazoo MI 49008, United States

e Department of Molecular Biology and Microbiology, Case Western Reserve University, Cleveland, Ohio 44106, United States

*Corresponding Author, Department of Chemistry and Biochemistry, University of WisconsinMilwaukee, Milwaukee, WI 53201, arnold2@uwm.edu

\section{Contents}

Table S1. Compound list with references

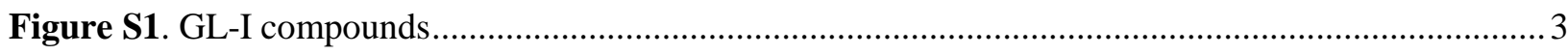

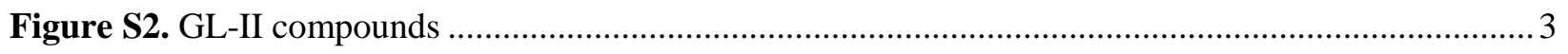

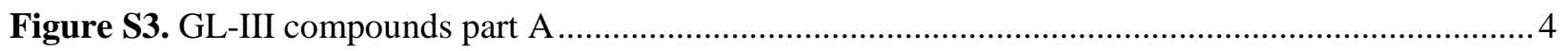

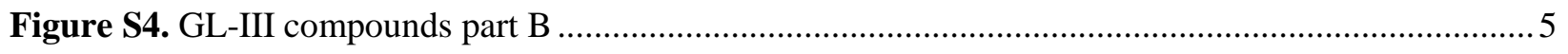

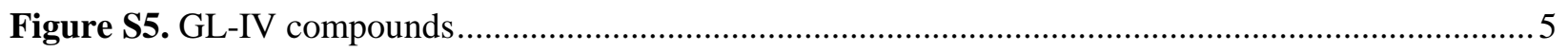

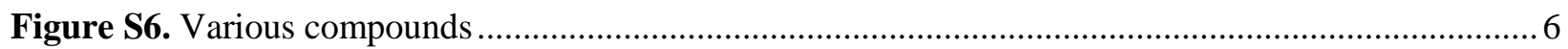

Figure S7. Concentration response of compounds with significant reduction of NO production for mouse microglia.

Figure S8. Concentration response of compounds with significant reduction of NO production for mouse macrophages (RAW267.4).

Figure S9. Concentration response of compounds with significant reduction of NO production for mouse microglia.

Figure S10. Concentration response of compounds with significant reduction of NO production for mouse macrophages (RAW267.4). 
Figure S11. Concentration dependent viability of HepG2 (liver) and HEK293 (kidney) in the presence of compounds from plate 1 .....

Figure S12. Concentration dependent viability of HepG2 (liver) and HEK293 (kidney) in the presence of compounds from plate 2 .

Figure S13. Concentration dependent viability of HepG2 (liver) and HEK293 (kidney) in the presence of compounds from plate 3 .

Figure S14. Concentration dependent viability of HepG2 (liver) and HEK293 (kidney) in the presence of compounds from plate 4

Figure S15. Concentration dependent viability of HepG2 (liver) and HEK293 (kidney) in the presence of compounds from plate 5

Figure S16. Concentration dependent viability of HepG2 (liver) and HEK293 (kidney) in the presence of compounds from plate 6 .

Figure S17. Concentration dependent viability of HepG2 (liver) and HEK293 (kidney) in the presence of compounds from plate 7 .

Figure S18. Concentration dependent viability of HepG2 (liver) and HEK293 (kidney) in the presence of compounds from plate 8 .

Table S2. PDSP Primary Screening Data for MP-IV-010.

Table S3. Human $\mathrm{GABA}_{\mathrm{A}} \mathrm{R}$ Subunit PCR Primers

Table S4. Mouse GABA ${ }_{A} R$ Subunit PCR Primers 16

References 16

Table S1. Compound list with references

\begin{tabular}{|c|c|c|c|c|c|}
\hline GL-I-48 ${ }^{1-3}$ & GL-II- $05^{4}$ & GL-III-13 ${ }^{5-7}$ & GL-III-70 ${ }^{8}$ & GL-IV-01 ${ }^{8}$ & DMH-D-053 $3^{1-3}$ \\
\hline GL-I-50 $0^{1,2}$ & GL-II- $06^{2}$ & ${\text { GL-III- } 23^{8}}^{2}$ & GL-III-72 $2^{5}$ & GL-IV-03 ${ }^{8}$ & KRM-II-18B $5,6,9$ \\
\hline GL-I-62 ${ }^{10}$ & GL-II-18 $2,8,11$ & GL-III- $24^{10}$ & GL-III-73 $^{5}$ & GL-IV-04 ${ }^{8}$ & KRM-II- $81^{5,6,9,12-14}$ \\
\hline GL-I-64 ${ }^{10}$ & GL-II-19 ${ }^{2,8,11}$ & GL-III- $25^{10}$ & GL-III-75 & GL-IV-05 ${ }^{15}$ & KRM-II- $82^{5,6}$ \\
\hline GL-I-65 & GL-II-32 & GL-III- $27^{10}$ & GL-III-76 ${ }^{5}$ & GL-IV-17 $8,11,16$ & MP-III-022 ${ }^{8}$ \\
\hline GL-I-66 ${ }^{8}$ & GL-II-33 ${ }^{8}$ & GL-III-35 & GL-III-76A ${ }^{5}$ & GL-IV-18 11,17 & MP-III- $080^{5,6,8,12}$ \\
\hline \multirow[t]{13}{*}{ GL-I-81 ${ }^{8}$} & GL-II-51 $^{11}$ & GL-III-36 & GL-III- $77^{5}$ & & MP-IV-004 ${ }^{8}$ \\
\hline & 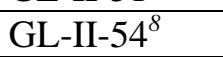 & GL-III- $42^{I I}$ & GL-III- $78^{5}$ & & MP-IV-005 \\
\hline & GL-II-61 ${ }^{10}$ & GL-III-52 ${ }^{18}$ & GL-III-84 & & MP-IV-010 \\
\hline & GL-II-79 5 & GL-III-53 ${ }^{11}$ & GL-III-85 & & QH-II-66 ${ }^{19}$ \\
\hline & GL-II- $80^{5}$ & GL-III-54 ${ }^{11}$ & GL-III-86 & & YT-III-271 ${ }^{1-3}$ \\
\hline & & GL-III-58 ${ }^{20}$ & GL-III-87 & & YT-III- $31^{5,7,21}$ \\
\hline & & GL-III-59 20 & GL-III-97 ${ }^{8}$ & & \\
\hline & & $\begin{array}{l}\text { GL-III-60 } \\
\text { GL-III-63 }^{22}\end{array}$ & GL-III-98 ${ }^{8}$ & & DMH-D-053 $3^{1-3}$ \\
\hline & & GL-III- $64^{8}$ & & & KRM-II-18B ${ }^{5,6,9}$ \\
\hline & & GL-III- $66^{8}$ & & & KRM-II- $81^{5,6,9,12-14}$ \\
\hline & & GL-III-67 $^{8}$ & & & KRM-II- $82^{5,6}$ \\
\hline & & GL-III-68 ${ }^{8}$ & & & \\
\hline & & GL-III-69 $^{8}$ & & & \\
\hline
\end{tabular}



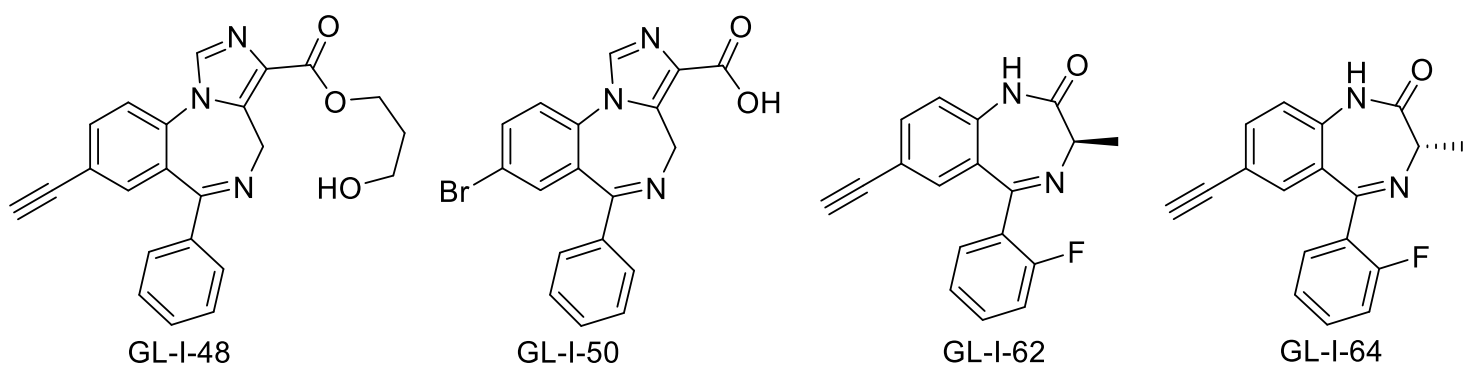

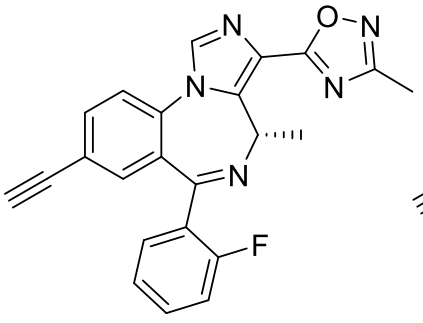

GL-I-65

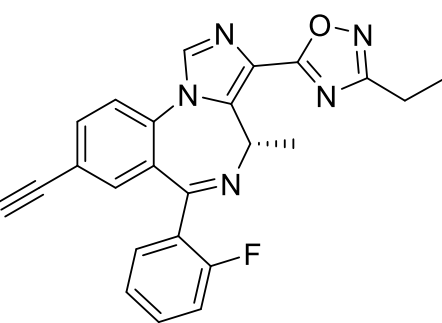

GL-I-66

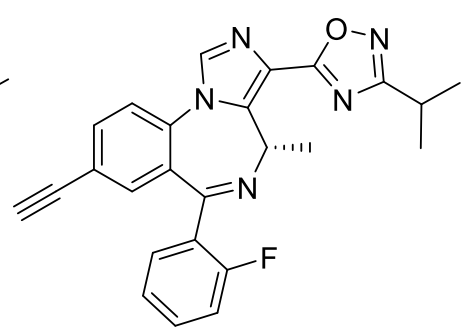

GL-I-81

Figure S1. GL-I compounds<smiles>CC1N=C(c2ccccn2)c2cc(Br)ccc2NC1=O</smiles>

GL-II-05<smiles></smiles>

GL-II-06<smiles>CC#Cc1ccc2c(c1)C(c1ccccn1)=N[C@@H](C)c1c(C(=O)OCC)ncn1-2</smiles>

GL-II-18<smiles>C#Cc1ccc2c(c1)C(c1ccccn1)=N[C@@H](C)c1c(C(=O)OCC)ncn1-2</smiles>

GL-II-19

SH-053-2'N-R-CH3<smiles>C#Cc1ccc2c(c1)C(c1ccc(Cl)nc1)=N[C@H](C)c1c(-c3nc(C)no3)ncn1-2</smiles><smiles>C[C@H]1N=C(c2ccccn2)c2cc(Br)ccc2-n2cnc(C(=O)O)c21</smiles><smiles>Cc1noc(-c2ncn3c2[C@@H](C)N=C(c2ccc[R19](Cl)(Cl)c2)c2cc(Br)ccc2-3)n1</smiles><smiles>C#Cc1ccc2c(c1)C(c1ccccn1)=N[C@H](C)C(=O)N2C</smiles>

GL-II-61<smiles>C#Cc1ccc2c(c1)C(c1ccc(Cl)cc1F)=NCc1c(C(=O)O)ncn1-2</smiles><smiles>C#Cc1ccc2c(c1)C(c1ccc(Cl)cc1F)=NCc1c(C(=O)OCCCO)ncn1-2</smiles>

Figure S2. GL-II compounds 

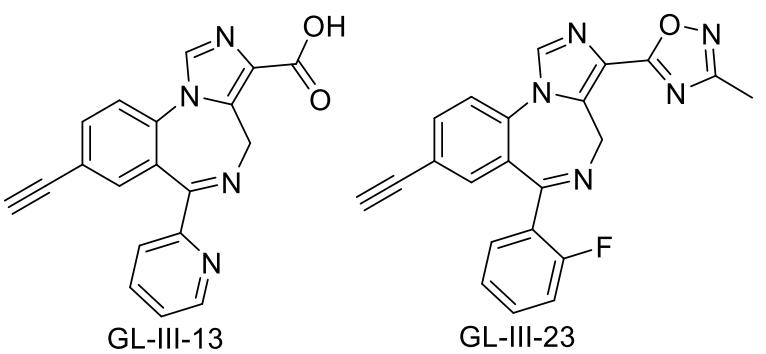

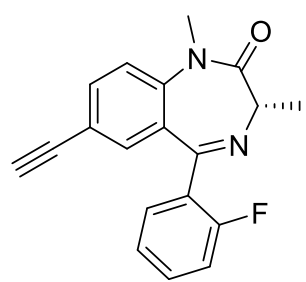

GL-III-24

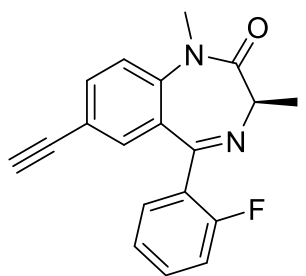

GL-III-25<smiles>C#Cc1ccc2c(c1)C(c1ccccn1)=N[C@@H](C)C(=O)N2</smiles>

GL-III-27<smiles>C[C@H]1N=C(c2ccccc2F)c2cc(Br)ccc2-n2cnc(C=O)c21</smiles>

GL-III-35<smiles>C[C@H]1N=C(c2ccccc2F)c2cc(Br)ccc2-n2cnc(-c3cnco3)c21</smiles>

GL-III-36<smiles>CCOC(=O)c1ncn2c1[C@H](C)N=C(c1ccccc1F)c1cc(C3CC3)ccc1-2</smiles>

GL-III-42<smiles>C[C@H]1N=C(c2ccccc2F)c2cc(Cl)ccc2NC1=O</smiles>

GL-III-52<smiles>CCOC(=O)c1ncn2c1[C@@H](C)N=C(c1ccccc1F)c1cc(Cl)ccc1-2</smiles>

GL-III-53<smiles>C[C@H]1N=C(c2ccccc2F)c2cc(Cl)ccc2-n2cnc(C(=O)O)c21</smiles>

GL-III-54<smiles>C#Cc1ccc2c(c1)C(c1cccc([13CH3])c1)=NCC(=O)N2</smiles>

GL-III-58<smiles>C#Cc1ccc2c(c1)C(c1ccccc1)=NCC(=O)N2</smiles>

GL-III-59<smiles>Cc1noc(-c2ncn3c2[C@@H](C)N=C(c2ccccc2F)c2cc(Br)ccc2-3)n1</smiles>

GL-III-60<smiles></smiles><smiles>C#Cc1ccc2c(c1)C(c1ccccc1F)=N[C@H](C)c1c(C(=O)NC(C)C)ncn1-2</smiles>

GL-III-66<smiles>CCNC(=O)c1ncn2c1[C@H](C)N=C(c1ccccc1F)c1cc(Br)ccc1-2</smiles>

GL-III-67

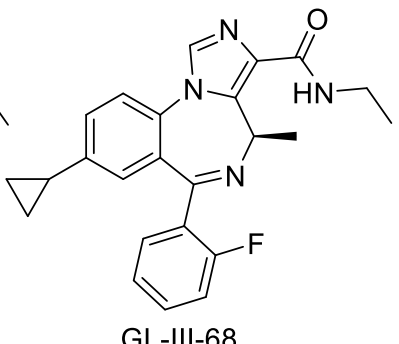

GL-III-68

Figure S3. GL-III compounds part A 

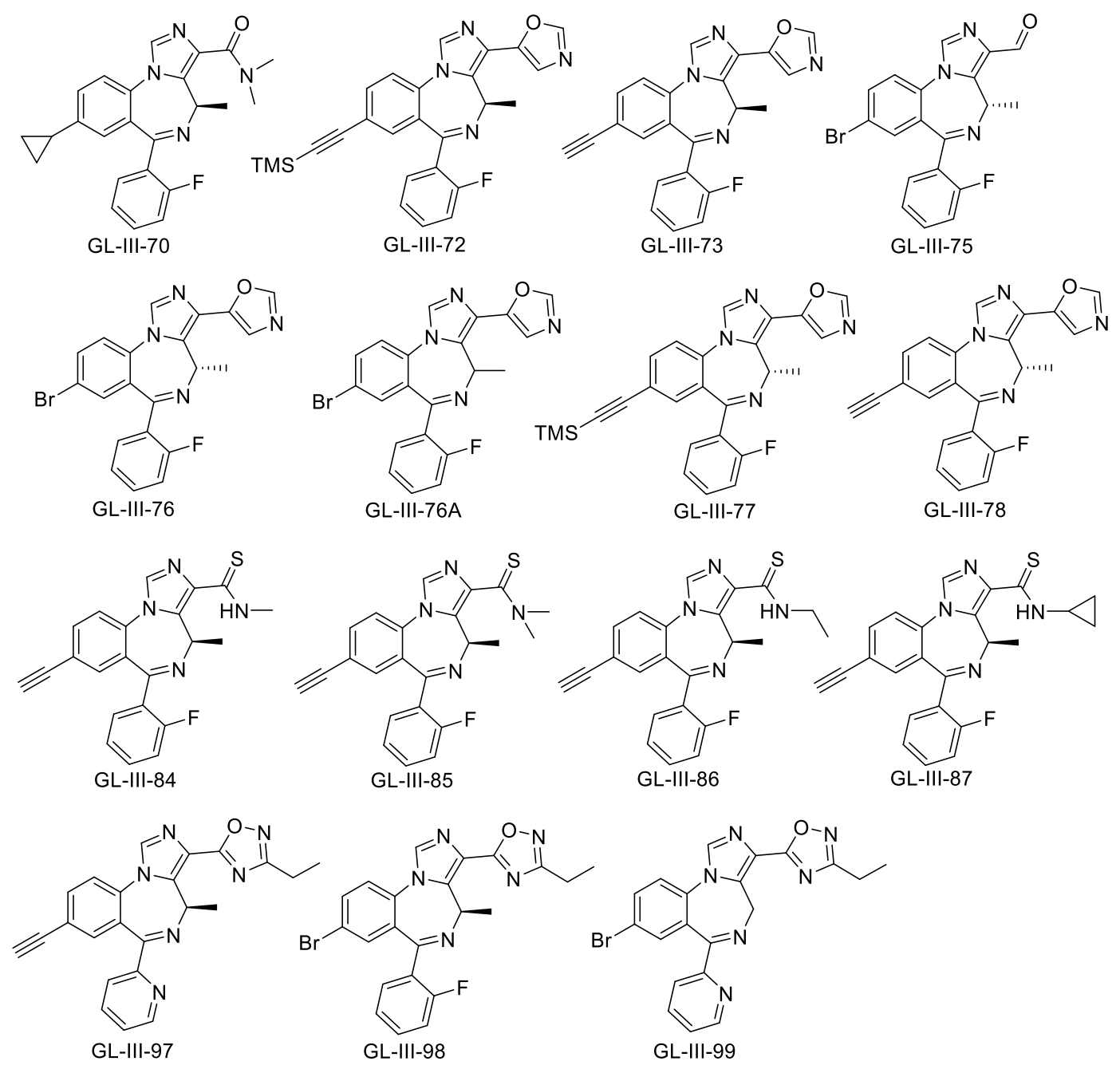

Figure S4. GL-III compounds part B
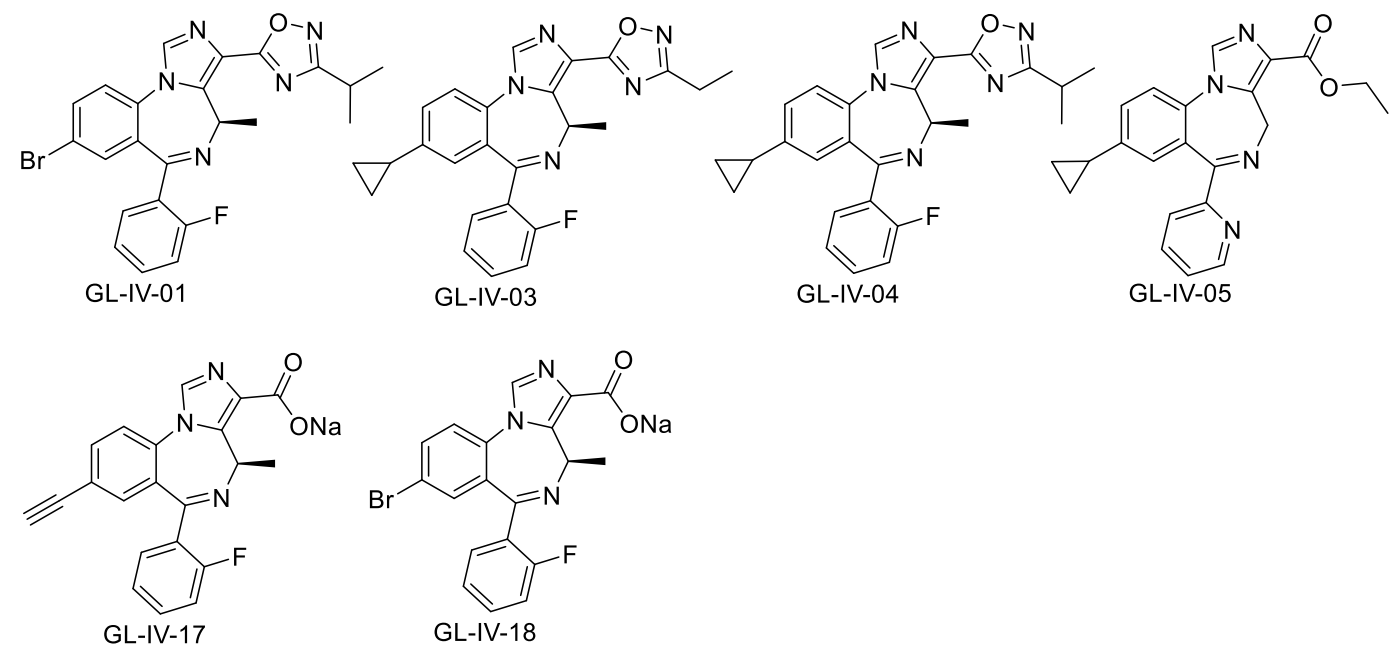

Figure S5. GL-IV compounds 


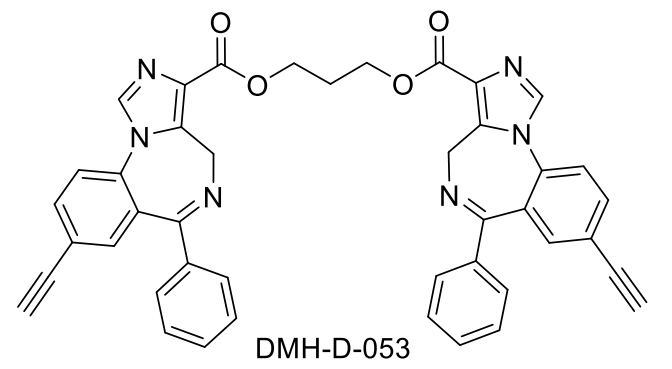

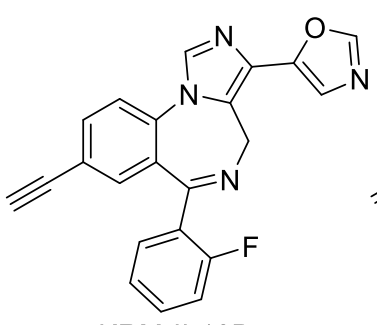

KRM-II-18B

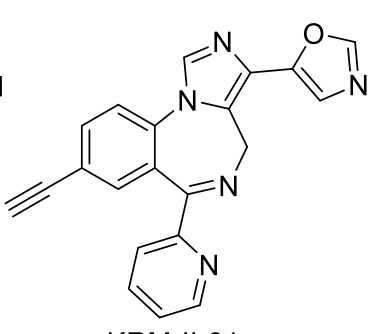

KRM-II-81<smiles>C#Cc1ccc2c(c1)C(c1ccccc1)=NCc1c(-c3cnco3)ncn1-2</smiles><smiles>C#Cc1ccc2c(c1)C(c1ccccn1)=NCc1c(-c3nc(CC)no3)ncn1-2</smiles><smiles>C#Cc1ccc2c(c1)C(c1ccccc1F)=NC(C)c1c(-c3nc(CC)no3)ncn1-2</smiles><smiles></smiles><smiles>C#Cc1ccc2c(c1)C(c1ccccc1)=NCC(=O)N2C</smiles><smiles>C#Cc1ccc2c(c1)C(c1ccccc1F)=NCC1=C(C(=O)OCCCOC(=O)c3ncn4c3CN=C(c3ccccc3F)c3cc(C#C)ccc3-4)CN=C12</smiles>

YT-III-271<smiles>C#Cc1ccc2c(c1)C(c1ccc(C#N)cc1)=NCc1c(C(=O)NC)ncn1-2</smiles>

Figure S6. Various compounds 

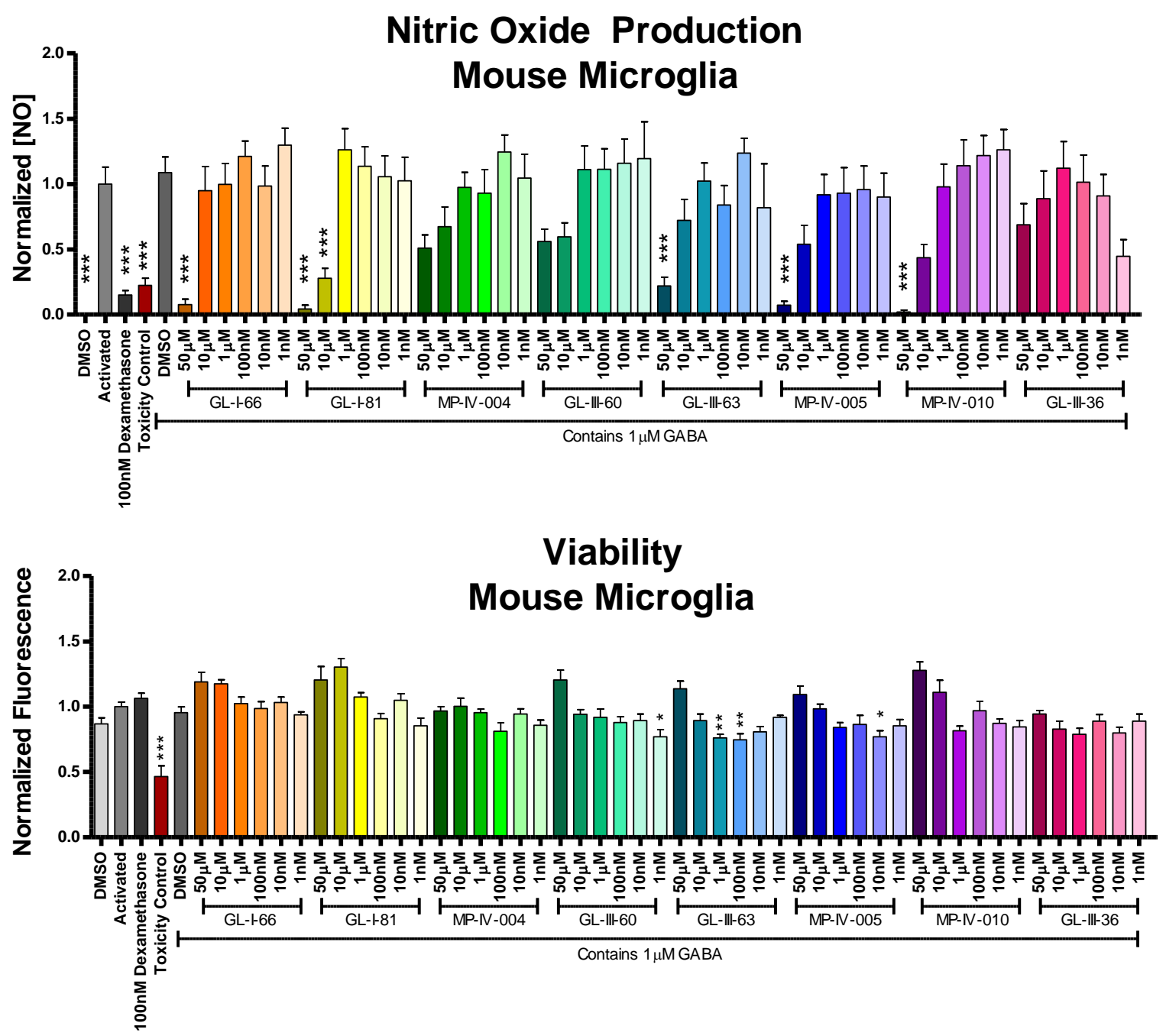

Figure S7. Concentration response of compounds with significant reduction of NO production for mouse microglia. A) Cells were activated with LPS and IFN $\gamma$ and treated with $1 \mu \mathrm{M}$ GABA and $1 \mathrm{nM}-50 \mu \mathrm{M}$ of compound for 24 hours. NO in supernatant was quantified with a Griess assay. B) ATP in remaining cells was quantified by the Cell Titer Glo as a measure of viability. Means \pm SEM are presented for $\mathrm{n}=12 . *{ }^{* *}$, and $* * *$ indicate $\mathrm{p}<0.05, \mathrm{p}<0.01$ and $\mathrm{p}<0.001$ respectively. (ANOVA) 
Nitric Oxide Production

RAW267.4 Cells

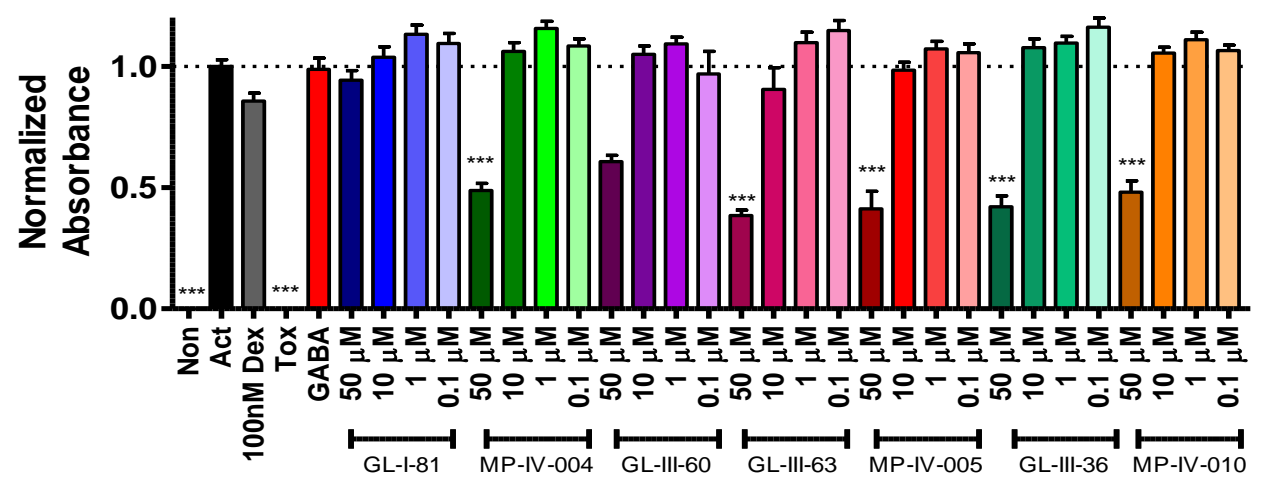

Viability

RAW267.4 Cells

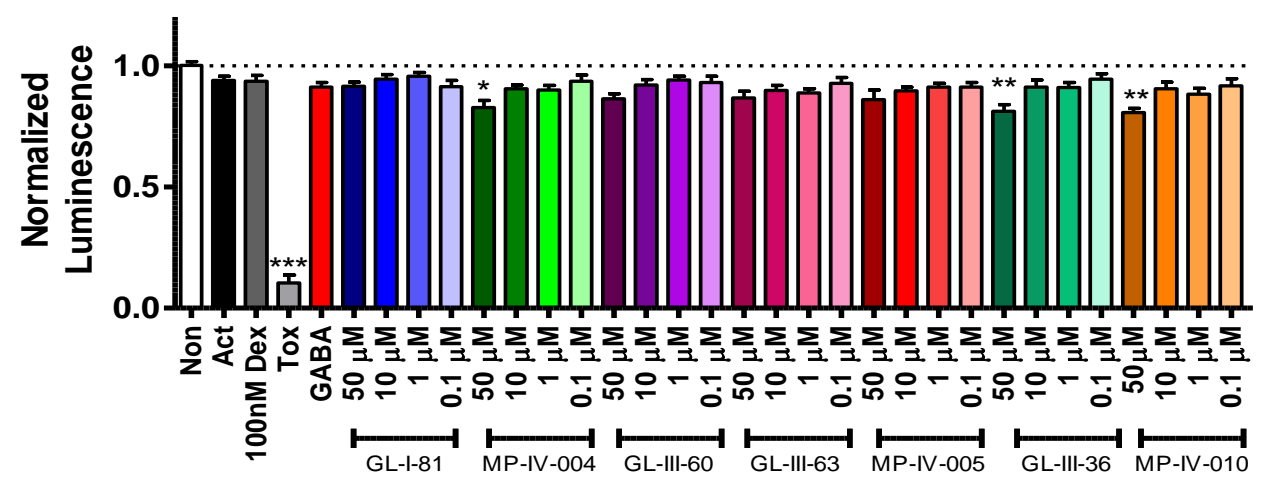

Figure S8. Concentration response of compounds with significant reduction of NO production for mouse macrophages (RAW267.4). A) Cells were activated with LPS and IFN $\gamma$ and treated with 1 $\mu \mathrm{M}$ GABA and $100 \mathrm{nM}-50 \mu \mathrm{M}$ of compound for 24 hours. NO in supernatant was quantified with a Griess assay. B) ATP in remaining cells was quantified by the Cell Titer Glo as a measure of viability. Means \pm SEM are presented for $\mathrm{n}=12 . *{ }^{* *}$, and $* * *$ indicate $\mathrm{p}<0.05, \mathrm{p}<0.01$ and $\mathrm{p}<0.001$ respectively. (ANOVA) 
Nitric Oxide Production

Mouse Microglia

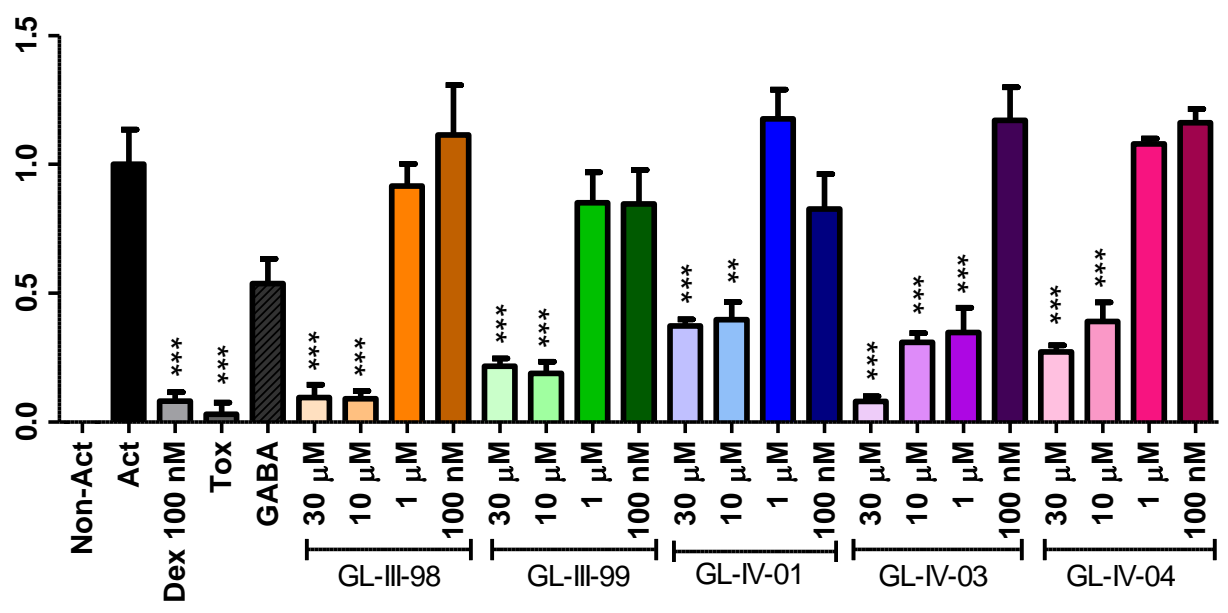

\section{Viability \\ Mouse Microglia}

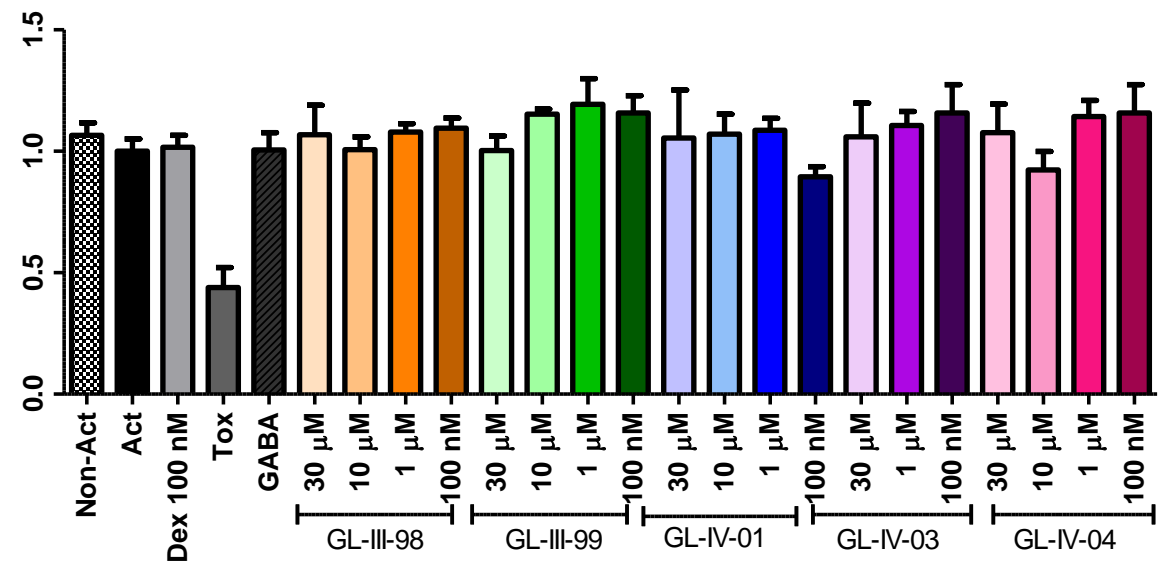

Figure S9. Concentration response of compounds with significant reduction of NO production for mouse microglia. A) Cells were activated with LPS and IFN $\gamma$ and treated with $1 \mu \mathrm{M}$ GABA and $100 \mathrm{nM}-30 \mu \mathrm{M}$ of compound for 24 hours. NO in supernatant was quantified with a Griess assay. B) ATP in remaining cells was quantified by the Cell Titer Glo as a measure of viability. Means \pm SEM are presented for $\mathrm{n}=12 . *, * *$, and $* * *$ indicate $\mathrm{p}<0.05, \mathrm{p}<0.01$ and $\mathrm{p}<0.001$ respectively. (ANOVA) 

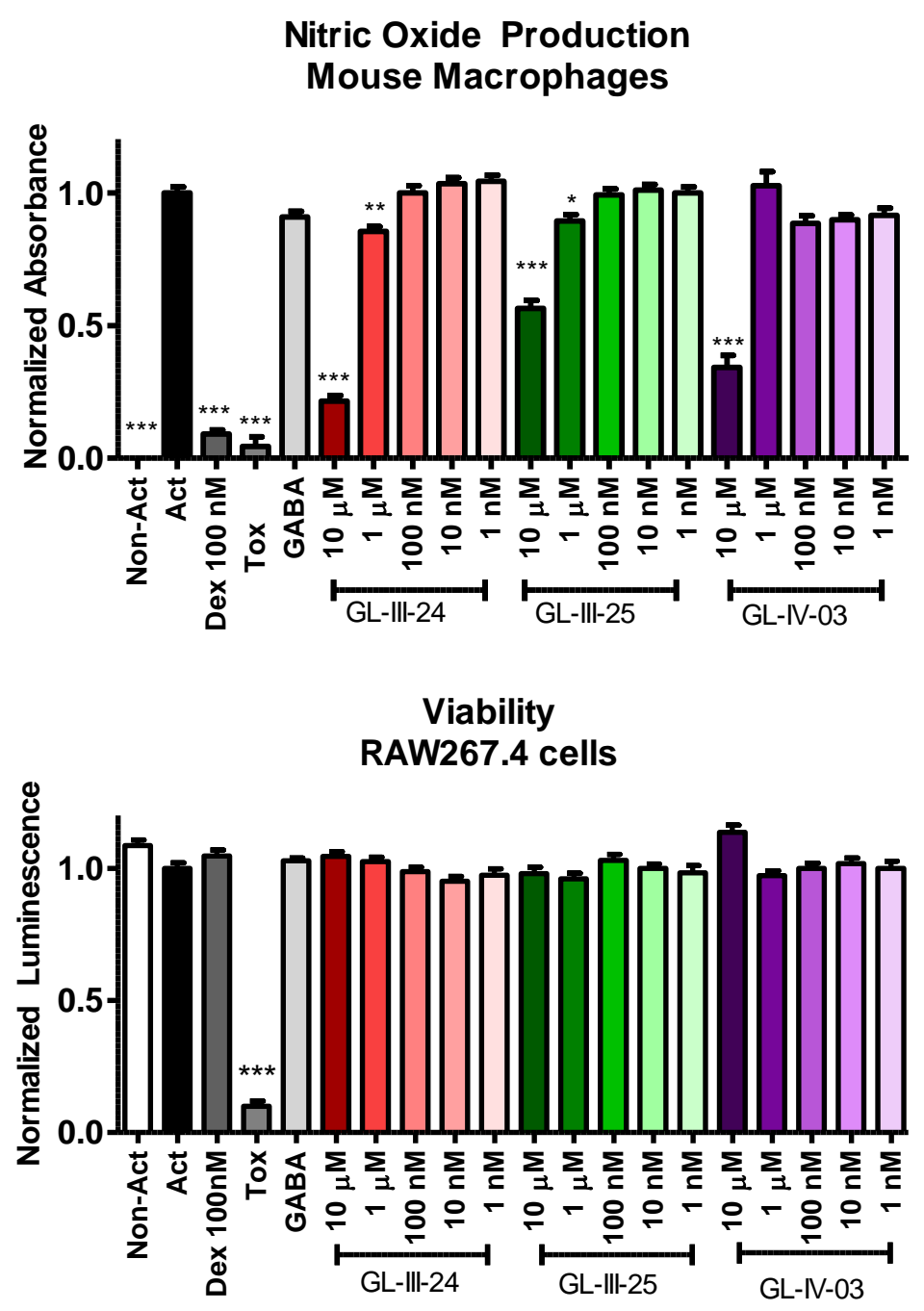

Figure S10. Concentration response of compounds with significant reduction of NO production for mouse macrophages (RAW267.4). A) Cells were activated with LPS and IFN $\gamma$ and treated with $1 \mu \mathrm{M}$ GABA and $1 \mathrm{nM}-10 \mu \mathrm{M}$ of compound for 24 hours. NO in supernatant was quantified with a Griess assay. B) ATP in remaining cells was quantified by the Cell Titer Glo as a measure of viability. Means \pm SEM are presented for $\mathrm{n}=12 . *, * *$, and $* * *$ indicate $\mathrm{p}<0.05, \mathrm{p}<0.01$ and $\mathrm{p}$ $<0.001$ respectively. (ANOVA) 

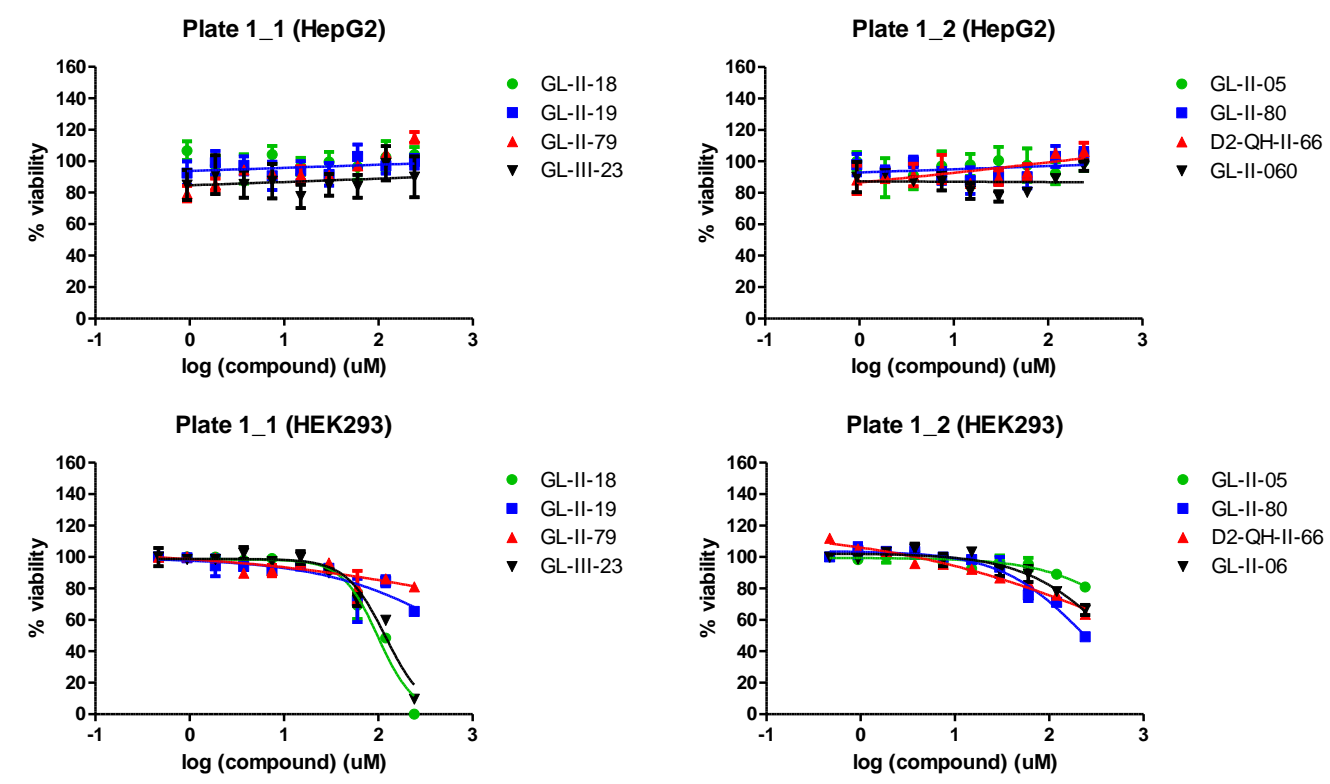

Figure S11. Concentration dependent viability of HepG2 (liver) and HEK293 (kidney) in the presence of compounds from plate 1. Cells were dispensed into 384 well plates and treated with different concentrations of compounds for 24 hours. The cell viability was determined with CellTiter-Glo. ( $\mathrm{n}=8$ for each concentration)
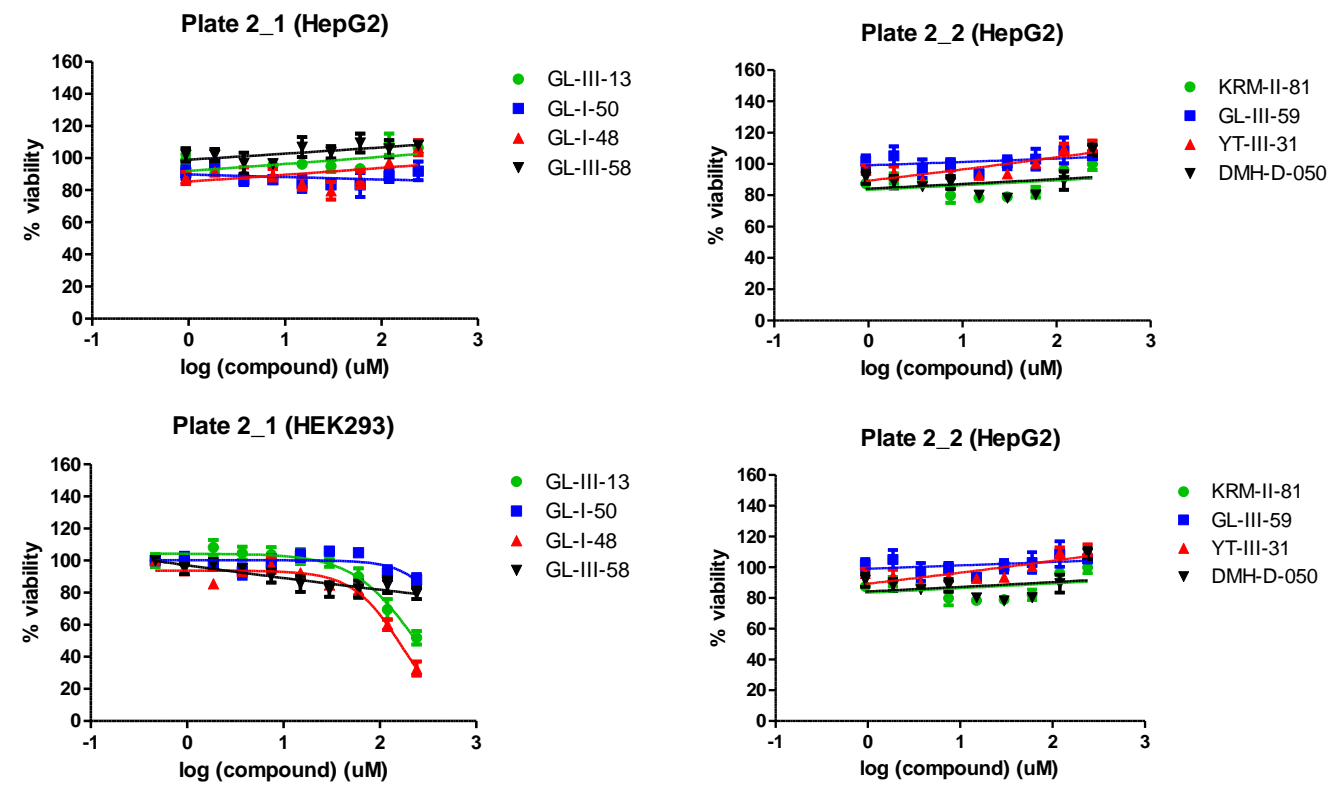

Figure S12. Concentration dependent viability of HepG2 (liver) and HEK293 (kidney) in the presence of compounds from plate 2. Cells were dispensed into 384 well plates and treated with different concentrations of compounds for 24 hours. The cell viability was determined with CellTiter-Glo. ( $\mathrm{n}=8$ for each concentration) 
Plate 3_1 (HepG2)
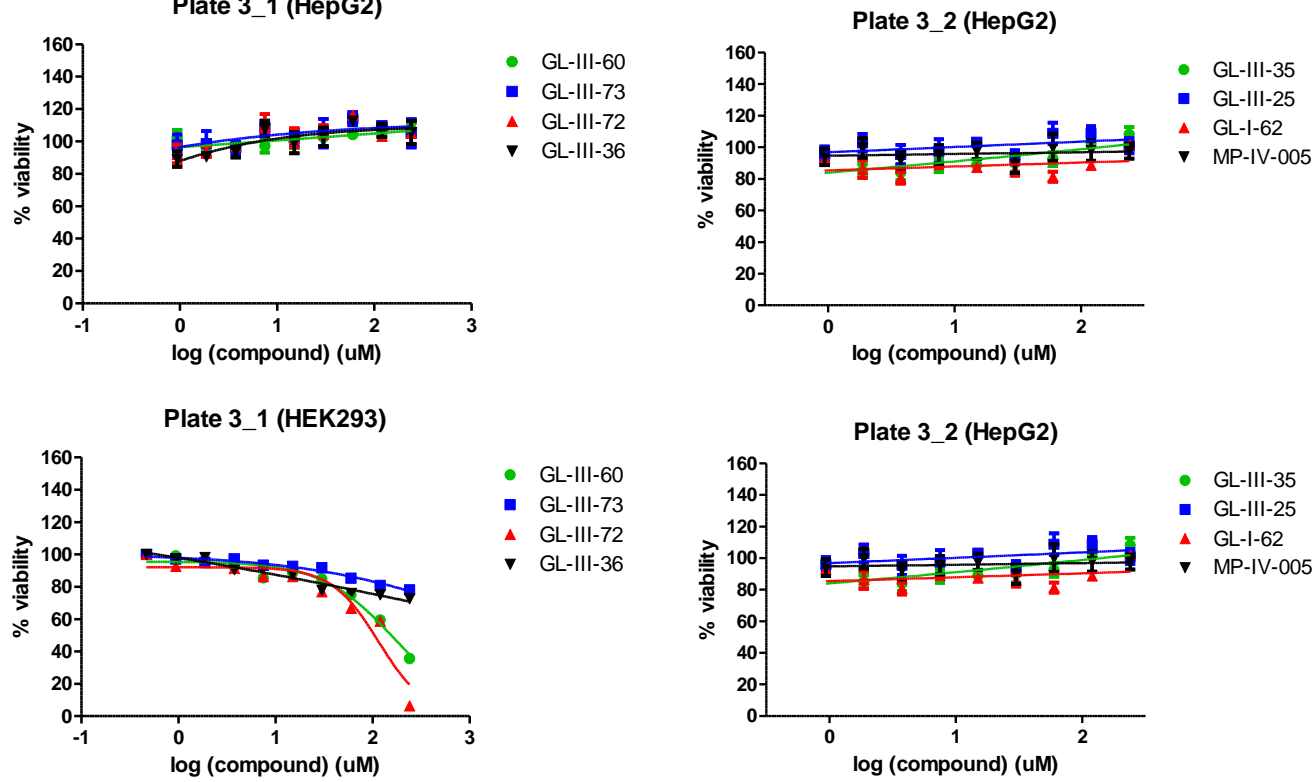

- GL-III-60

- GL-III-73

$\triangle$ GL-III-72

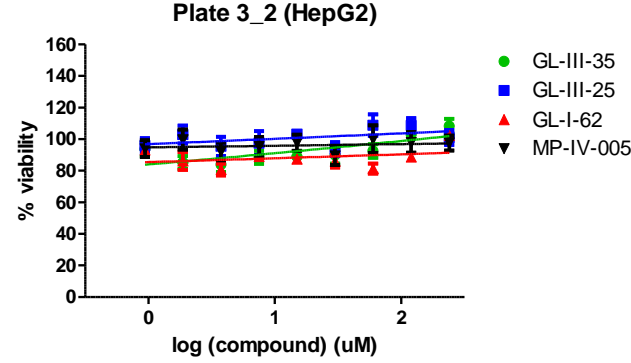

Figure S13. Concentration dependent viability of HepG2 (liver) and HEK293 (kidney) in the presence of compounds from plate 3. Cells were dispensed into 384 well plates and treated with different concentrations of compounds for 24 hours. The cell viability was determined with CellTiter-Glo. ( $\mathrm{n}=8$ for each concentration)
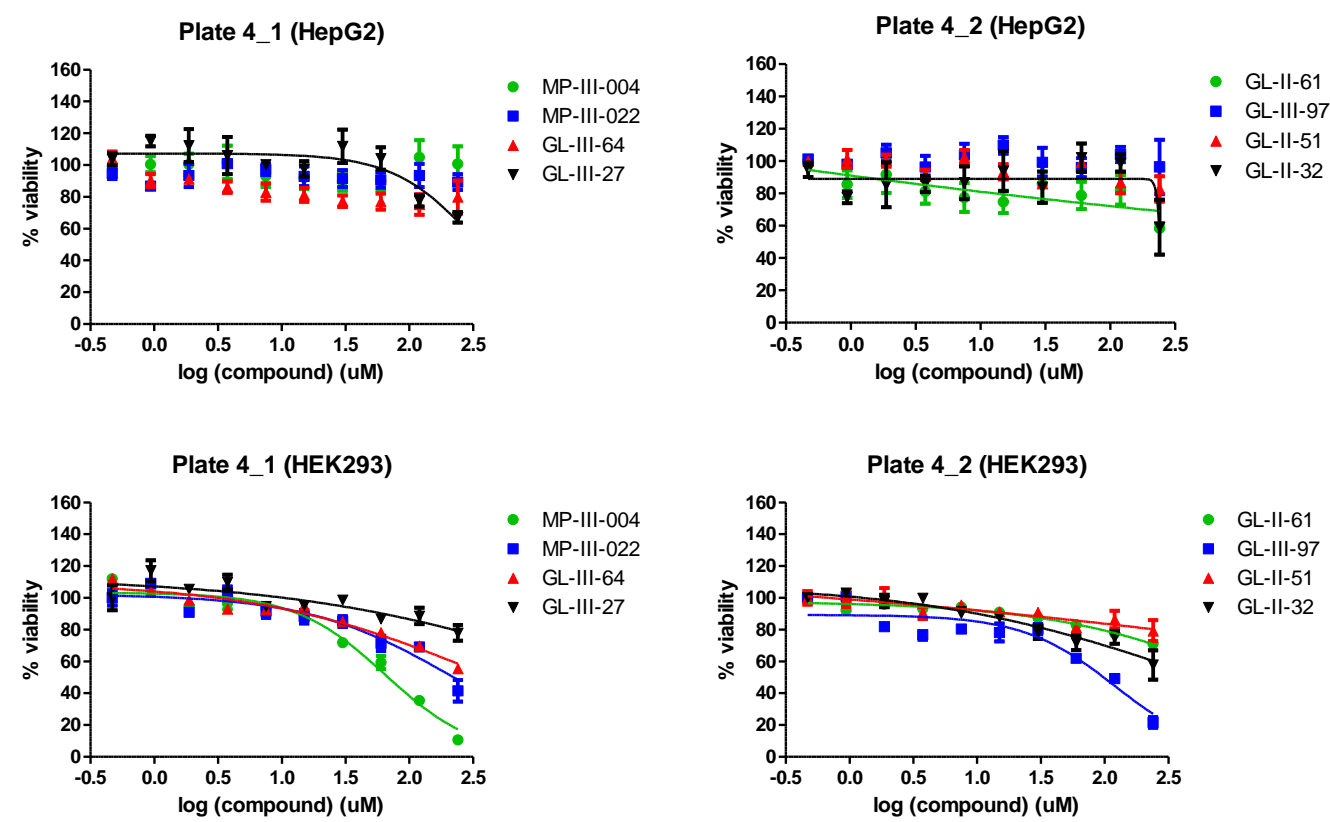

Figure S14. Concentration dependent viability of HepG2 (liver) and HEK293 (kidney) in the presence of compounds from plate 4. Cells were dispensed into 384 well plates and treated with different concentrations of compounds for 24 hours. The cell viability was determined with CellTiter-Glo. ( $\mathrm{n}=8$ for each concentration) 

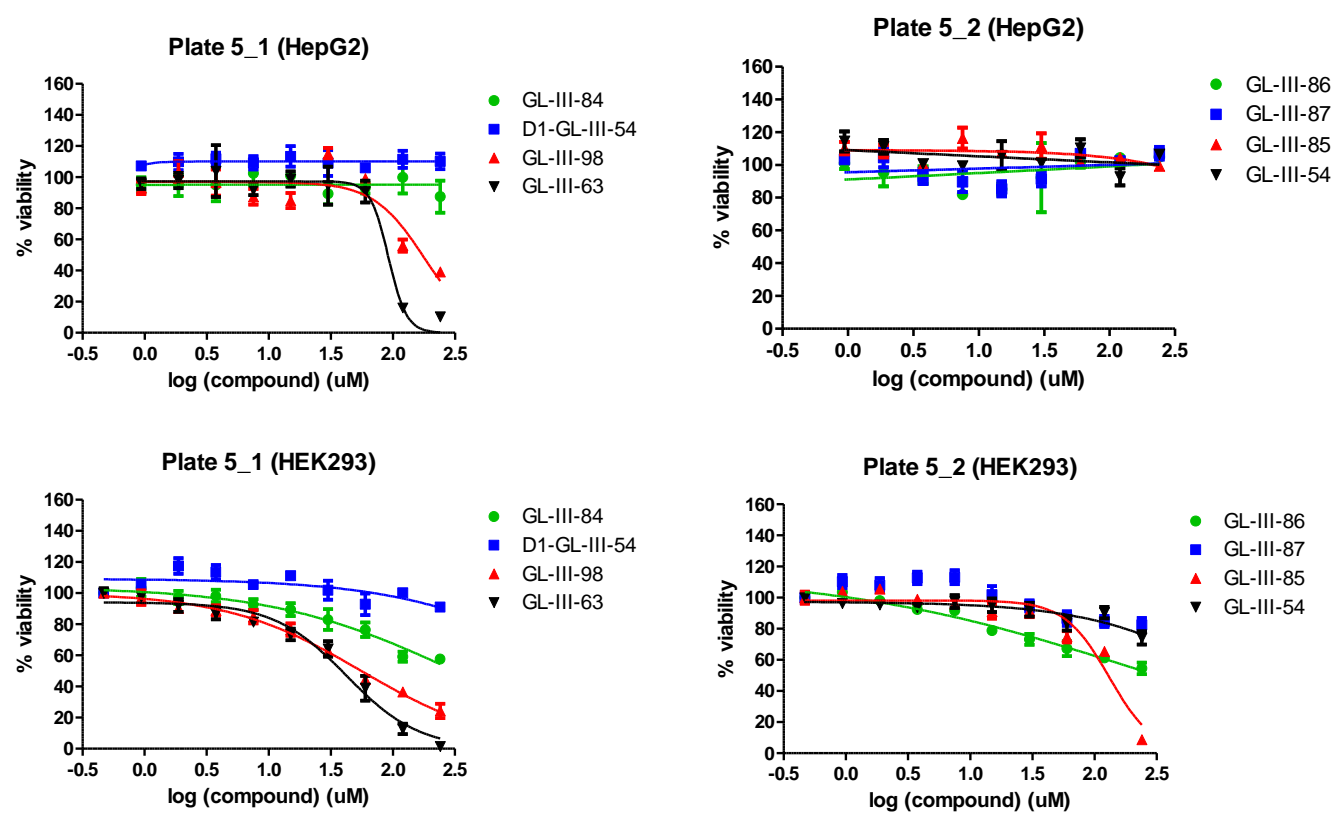

Figure S15. Concentration dependent viability of HepG2 (liver) and HEK293 (kidney) in the presence of compounds from plate 5. Cells were dispensed into 384 well plates and treated with different concentrations of compounds for 24 hours. The cell viability was determined with CellTiter-Glo. ( $\mathrm{n}=8$ for each concentration)
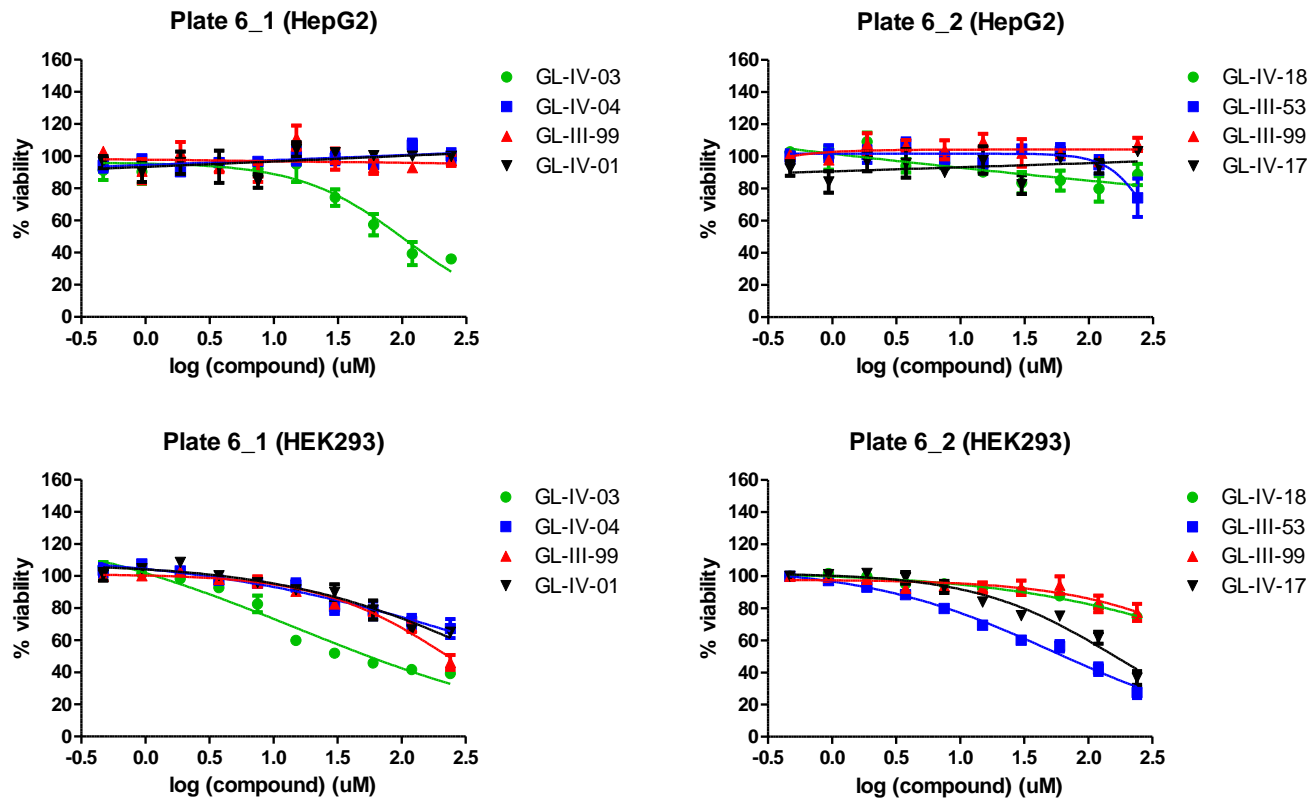

Figure S16. Concentration dependent viability of HepG2 (liver) and HEK293 (kidney) in the presence of compounds from plate 6 . Cells were dispensed into 384 well plates and treated with different concentrations of compounds for 24 hours. The cell viability was determined with CellTiter-Glo. ( $\mathrm{n}=8$ for each concentration) 

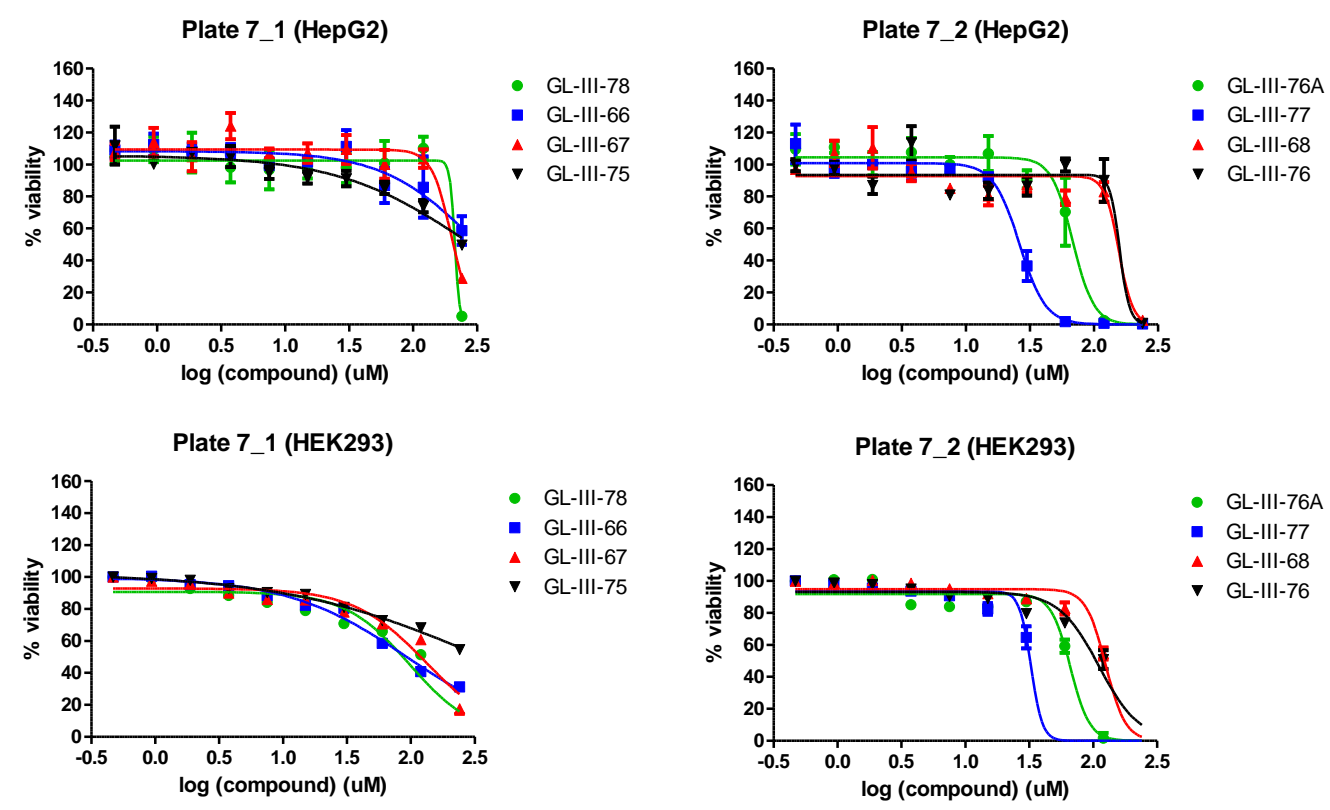

Figure S17. Concentration dependent viability of HepG2 (liver) and HEK293 (kidney) in the presence of compounds from plate 7. Cells were dispensed into 384 well plates and treated with different concentrations of compounds for 24 hours. The cell viability was determined with CellTiter-Glo. ( $\mathrm{n}=8$ for each concentration)

Plate 8_1 (HepG2)

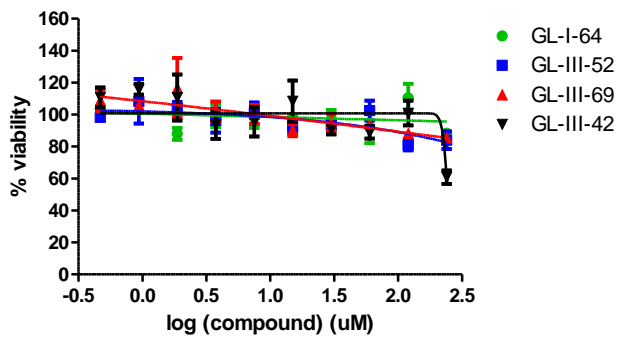

Plate 8_1 (HEK293)

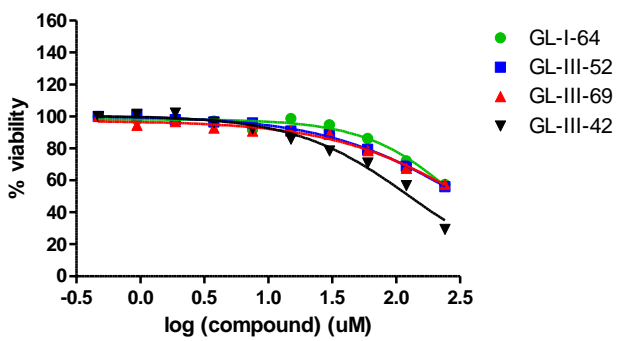

Plate 8_2 (HepG2)

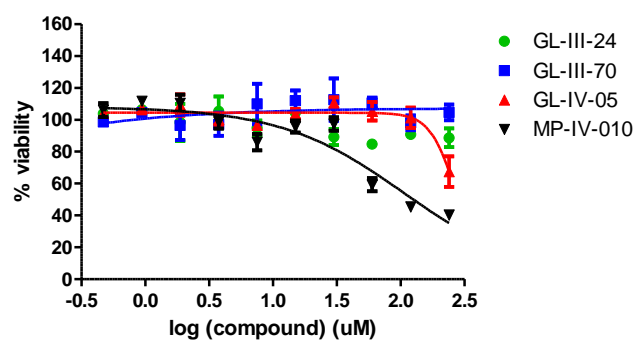

Plate 8_2 (HEK293)

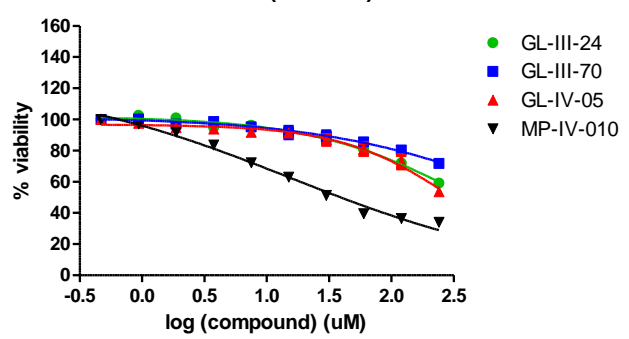

Figure S18. Concentration dependent viability of HepG2 (liver) and HEK293 (kidney) in the presence of compounds from plate 8 . Cells were dispensed into 384 well plates and treated with different concentrations of compounds for 24 hours. The cell viability was determined with CellTiter-Glo. ( $\mathrm{n}=8$ for each concentration) 
Table S2. PDSP Primary Screening Data for MP-IV-010.

\begin{tabular}{cc|cc|cc}
\hline Receptor & $\begin{array}{c}\text { Percent } \\
\text { Competition }\end{array}$ & Receptor & $\begin{array}{c}\text { Percent } \\
\text { Competition }\end{array}$ & Receptor & $\begin{array}{c}\text { Percent } \\
\text { Competition }\end{array}$ \\
\hline 5-HT1A & 19 & D5 & 29 & Alpha2A & 14 \\
\hline 5-HT1B & 29 & SERT & 22 & Alpha2B & 29 \\
\hline 5-HT1D & 6 & NET & -2 & Alpha2C & 31 \\
\hline 5-HT1E & -7 & DAT & 14 & Beta1 & 6 \\
\hline 5-HT2A & -1 & MOR & 33 & Beta2 & 20 \\
\hline 5-HT2B & 0 & DOR & 5 & M1 & -11 \\
\hline 5-HT2C & -2 & KOR & 94 & M2 & 10 \\
\hline 5-HT3 & 13 & GABAA & -8 & M3 & 0 \\
\hline 5-HT5A & 11 & H1 & 19 & M4 & 8 \\
\hline 5-HT6 & 21 & H2 & 28 & M5 & 26 \\
\hline 5-HT7 & -5 & H3 & -18 & Beta3 & 38 \\
\hline D1 & 28 & H4 & 6 & BZP Rat Brain & 64 \\
\hline D2 & 25 & Calcium Channel & 15 & Site & 28 \\
\hline D3 & 15 & Alpha1A & 2 & Alpha1D & 9 \\
\hline D4 & 5 & Alpha1B & 15 & HERG binding & 29 \\
\hline & & & & Sigma 2 & 64 \\
\hline
\end{tabular}

Table S3. Human GABA $A_{A} R$ Subunit PCR Primers

\begin{tabular}{lllll}
$\begin{array}{c}\text { GABA } \\
\begin{array}{c}\text { R } \\
\text { Subunit }\end{array}\end{array}$ & \multicolumn{1}{c}{ Forward } & \multicolumn{1}{c}{ Reverse } & Size & Ref \\
\hline GAPDH & ACC ACA GTC CAT GCC ATC AC & TCC ACC ACC CTG TTG CTG TA & 452 & 23 \\
\hline$\alpha 1$ & GGA TTG GGA GAG CGT GTA ACC & TGA AAC GGG TCC GAA ACT G & 66 & 23 \\
\hline$\alpha 2$ & GTT CAA GCT GAA TGC CCA AT & ACC TAG AGC CAT CAG GAG CA & 160 & 23 \\
\hline$\alpha 3$ & CAA CTT GTT TCA GTT CAT TCA & CTT GTT TGT GTG ATT ATC ATC TTC TTA & 102 & \\
& TCC TT & GG & 105 & 23 \\
\hline$\alpha 4$ & TTG GGG GTC CTG TTA CAG AAG & TCT GCC TGA AGA ACA CAT CCA & 105 & 23 \\
\hline$\alpha 5$ & CTT CTC GGC GCT GAT AGA GT & CGC TTT TTC TTG ATC TTG GC & 109 & 24 \\
\hline$\alpha 6$ & CTG AAC CTT TGG AAG CTG AGA & TTA TTG GCC TCG GAA GAT GA & 102 & 23 \\
\hline$\beta 1$ & CCA GGT CGA CGC CCA CGG TA & GTG GCC TTG GGG TCG CTC AC & 137 & 23 \\
\hline$\beta 2$ & GCA GAG TGT CAA TGA CCC TAG T & GGC AAT GTC AAT GTT CAT CCC & 105 & 23 \\
\hline$\beta 3$ & CCG TTC AAA GAG CGA AAG CAA & TCG CCA ATG CCG CCT GAG AC & & \\
\hline$\gamma 1$ & CCG & & 91 & 23 \\
\hline$\gamma 2$ & CCT TTT CTT CTG CGG AGT CAA & CAT CTG CCT TAT CAA CAC AGT TTC C & 91 \\
\hline$\gamma 3$ & CAC AGA AAA TGA CGG TGT GG & TCA CCC TCA GGA ACT TTT GG & 136 & 23 \\
\hline$\delta$ & AAC CAA CCA CCA CGA AGA AGA & CCT CAT GTC CAG GAG GGA AT & 131 & 23 \\
\hline
\end{tabular}


Table S4. Mouse GABA ${ }_{A} R$ Subunit PCR Primers

\begin{tabular}{lllcc}
$\begin{array}{c}\text { GABA } \\
\text { R } \\
\text { Subunit }\end{array}$ & \multicolumn{1}{c}{ Forward } & \multicolumn{1}{c}{ Reverse } & Size & $\begin{array}{c}\text { Re } \\
\mathbf{f}\end{array}$ \\
\hline$\alpha 1$ & CAA GAG CAG AAG TTG TCT ATG AGT & GCA CGG CAG ATA TGT TTG AAT AAC & 215 & 26 \\
\hline$\alpha 2$ & GCT ACG CTT ACA CAA CCT CAG A & GAC TGG CCC AGC AAA TCA TAC T & 115 & 26 \\
\hline$\alpha 3$ & GCC GTC TGT TAT GCC TTT GTA TTT & TTC TTC ATC TCC AGG GCC TCT & 119 & 27 \\
\hline$\alpha 4$ & AGA ACT CAA AGG ACG AGA AAT TGT & TTC ACT TCT GTA ACA GGA CCC C & 118 & 23 \\
\hline$\alpha 5$ & AAG TTC GCT CCG GCA GTA TG & TGT TCT TGC CTC CAA CTT GAT CT & 149 & 27 \\
\hline$\alpha 6$ & CTT GCT GGA AGG CTA TGA CAA C & AAG TCT GGC GGA AGA AAA CAT C & 146 & 27 \\
\hline$\beta 1$ & GGT TTG TTG TGC ACA CAG CTC C & ATG CTG GCG ACA TCG ATC CGC & 153 & 23 \\
\hline$\beta 2$ & GCT GGT GAG GAA ATC TCG GTC CC & CAT GCG CAC GGC GTA CCA AA & 70 & 23 \\
\hline$\beta 3$ & CTT TGC GGG AGG AAG GCT TT & GGG GTC GTT TAC GCT CTG AG & 85 & 27 \\
\hline$\gamma 1$ & ATC CAC TCT CAT TCC CAT GAA CAG & ACA GAA AAA GCT AGT ACA GTC TTT & 100 & 23 \\
\hline & C & GC & 147 & 26 \\
\hline$\gamma 2$ & ACT TCT GGT GAC TAT GTG GTG AT & GGC AGG AAC AGC ATC CTT ATT G & 147 \\
\hline$\gamma 3$ & ATT ACA TCC AGA TTC CAC AAG ATG & CAC AGG TGT CCT CAA ATT CCT & 149 & 23 \\
\hline$\delta$ & TCA AAT CGG CTG GCC AGT TCC C & GCA CGG CTG CCT GGC TAA TCC & 147 & 28 \\
\hline GAPDH & AAC ACA GTC CAT GCC ATC AC & CAC CAC CCT GTT GCT GTA GCC & 450 & 23 \\
\hline & & & 23 \\
\hline
\end{tabular}

\section{References}

1. Han, D., Holger Forsterling, F., Li, X., Deschamps, J. R., Parrish, D., Cao, H., Rallapalli, S., Clayton, T., Teng, Y., Majumder, S., Sankar, S., Roth, B. L., Sieghart, W., Furtmuller, R.,

Rowlett, J. K., Weed, M. R., and Cook, J. M. (2008) A study of the structure-activity relationship of GABA(A)-benzodiazepine receptor bivalent ligands by conformational analysis with low temperature NMR and X-ray analysis. Bioorg. Med. Chem. 16, 8853-8862.

2. Cook, J. M., Huang, S., Edwankar, C. R., Namjoshi, O. A., and Wang, Z.-J. (2010) Selective Agents for Pain Suppression, US20100317619.

3. Han, D., Forsterling, F. H., Li, X., Deschamps, J. R., Cao, H., and Cook, J. M. (2004)

Determination of the stable conformation of GABA(A)-benzodiazepine receptor bivalent ligands by low temperature NMR and X-ray analysis. Bioorg. Med. Chem. Lett. 14, 1465-1469.

4. Fryer, R. I., Schmidt, R. A., and Sternbach, L. H. (1964) Quinazolines and 1,4-

Benzodiazepines XVII: Synthesis of 1,3-Dihydro-5-pyridyl-2H-1,4-benzodiazepine Derivatives.

J. Pharm. Sci. 53, 264-268.

5. Cook, J. M., Poe, M. M., Methuku, K. R., and Li, G. (2016) Gabaergic Ligands and Their Uses, WO2016154031.

6. Poe, M. M., Methuku, K. R., Li, G., Verma, A. R., Teske, K. A., Stafford, D. C., Arnold, L. A., Cramer, J. W., Jones, T. M., Cerne, R., Krambis, M. J., Witkin, J. M., Jambrina, E., Rehman, S., Ernst, M., Cook, J. M., and Schkeryantz, J. M. (2016) Synthesis and Characterization of a Novel gamma-Aminobutyric Acid Type A (GABAA) Receptor Ligand That Combines Outstanding Metabolic Stability, Pharmacokinetics, and Anxiolytic Efficacy. J. Med. Chem. 59, 10800-10806.

7. Namjoshi, O. A., Wang, Z. J., Rallapalli, S. K., Johnson, E. M., Jr., Johnson, Y. T., Ng, H., Ramerstorfer, J., Varagic, Z., Sieghart, W., Majumder, S., Roth, B. L., Rowlett, J. K., and Cook, J. M. (2013) Search for alpha3beta(2)/(3)gamma2 subtype selective ligands that are stable on human liver microsomes. Bioorg. Med. Chem. 21, 93-101.

8. Cook, J. M., Li, G., Poe, M. M., Savic, M. M., and Sibille, E. (2017) Treatment of Cognitive and Mood Symptoms in Neurodegenerative and Neuropsychiatric Disorders with Alpha-5Containing GABA(A) Receptor Agonists, WO2017161370. 
9. Lewter, L. A., Fisher, J. L., Siemian, J. N., Methuku, K. R., Poe, M. M., Cook, J. M., and Li, J. X. (2017) Antinociceptive Effects of a Novel alpha2/alpha3-Subtype Selective GABAA Receptor Positive Allosteric Modulator. ACS Chem. Neurosci. 8, 1305-1312.

10. Cook, J. M., Zhou, H., Huang, S., Sarma, P. V. V. S., and Zhang, C. (2006) Stereospecific Anxiolytic and Anticonvulsant Agent with Reduced Muscle-Relaxant, Sedative, Hypnotic, and Ataxic Effects, US20060003995.

11. Arnold, A. E., Stafford, D. C., Cook, J. M., Emala, C. W., Forkuo, G. S., Jahan, R., Kodali, R., Li, G., and Stephen, M. R. (2018) GABA(A) Receptor Modulators and Methods to Control Airway Hyperresponsiveness and Inflammation in Asthma, WO2018035246.

12. Witkin, J. M., Cerne, R., Wakulchik, M., S, J., Gleason, S. D., Jones, T. M., Li, G., Arnold, L. A., Li, J. X., Schkeryantz, J. M., Methuku, K. R., Cook, J. M., and Poe, M. M. (2017) Further evaluation of the potential anxiolytic activity of imidazo[1,5-a][1,4]diazepin agents selective for alpha2/3-containing GABAA receptors. Pharmacol. Biochem. Behav. 157, 35-40.

13. Witkin, J. M., Ping, X., Cerne, R., Mouser, C., Jin, X., Hobbs, J., Tiruveedhula, V., Li, G., Jahan, R., Rashid, F., Kumar Golani, L., Cook, J. M., and Smith, J. L. (2019) The value of human epileptic tissue in the characterization and development of novel antiepileptic drugs: The example of CERC-611 and KRM-II-81. Brain Res. 1722, 146356.

14. Moerke, M. J., Li, G., Golani, L. K., Cook, J., and Negus, S. S. (2019) Effects of the alpha2/alpha3-subtype-selective GABAA receptor positive allosteric modulator KRM-II-81 on pain-depressed behavior in rats: comparison with ketorolac and diazepam. Behav. Pharmacol. $30,452-461$.

15. Cook, J. M., Huang, Q., He, X., Li, X., Yu, J., Han, D., Lelas, S., and McElroy, J. F. (2004) Anxiolytic Agents with Reduced Sedative and Ataxic Effects, US7119196B2.

16. Forkuo, G. S., Nieman, A. N., Yuan, N. Y., Kodali, R., Yu, O. B., Zahn, N. M., Jahan, R., Li, G., Stephen, M. R., Guthrie, M. L., Poe, M. M., Hartzler, B. D., Harris, T. W., Yocum, G. T., Emala, C. W., Steeber, D. A., Stafford, D. C., Cook, J. M., and Arnold, L. A. (2017) Alleviation of Multiple Asthmatic Pathologic Features with Orally Available and Subtype Selective GABAA Receptor Modulators. Mol. Pharm. 14, 2088-2098.

17. Forkuo, G. S., Nieman, A. N., Kodali, R., Zahn, N. M., Li, G., Rashid Roni, M. S., Stephen, M. R., Harris, T. W., Jahan, R., Guthrie, M. L., Yu, O. B., Fisher, J. L., Yocum, G. T., Emala, C. W., Steeber, D. A., Stafford, D. C., Cook, J. M., and Arnold, L. A. (2018) A Novel Orally Available Asthma Drug Candidate That Reduces Smooth Muscle Constriction and Inflammation by Targeting GABAA Receptors in the Lung. Mol. Pharm. 15, 1766-1777.

18. Fryer, R. I., Coffen, D. L., Earley, J. V., and Walser, A. (1973) Quinazolines and 1,4benzodiazepines LVII†. 1H-1,4-benzodiazepines. J Heterocylic Chem 10, 473-478.

19. Huang, Q., He, X., Ma, C., Liu, R., Yu, S., Dayer, C. A., Wenger, G. R., McKernan, R., and Cook, J. M. (2000) Pharmacophore/receptor models for GABA(A)/BzR subtypes (alpha1beta3gamma2, alpha5beta3gamma2, and alpha6beta3gamma2) via a comprehensive ligand-mapping approach. J. Med. Chem. 43, 71-95.

20. Kallay, L., Keskin, H., Ross, A., Rupji, M., Moody, O. A., Wang, X., Li, G., Ahmed, T., Rashid, F., Stephen, M. R., Cottrill, K. A., Nuckols, T. A., Xu, M., Martinson, D. E., Tranghese, F., Pei, Y., Cook, J. M., Kowalski, J., Taylor, M. D., Jenkins, A., Pomeranz Krummel, D. A., and Sengupta, S. (2019) Modulating native GABAA receptors in medulloblastoma with positive allosteric benzodiazepine-derivatives induces cell death. J. Neurooncol. 142, 411-422.

21. Meng, Z., Berro, L. F., Sawyer, E. K., Ruedi-Bettschen, D., Cook, J. E., Li, G., Platt, D. M., Cook, J. M., and Rowlett, J. K. (2020) Evaluation of the anti-conflict, reinforcing, and sedative 
effects of YT-III-31, a ligand functionally selective for alpha3 subunit-containing GABAA receptors. J Psychopharmacol 34, 348-357.

22. Cook, J., Clayton, T., Johnson, Y. T., Rallapalli, S., and Han, D. (2010) Gabaergic Agents to Treat Memory Deficits, EP1888594A2.

23. Mendu, S. K., Bhandage, A., Jin, Z., and Birnir, B. (2012) Different subtypes of GABA-A receptors are expressed in human, mouse and rat T lymphocytes. PLoS One 7, e42959.

24. Braun, M., Ramracheya, R., Bengtsson, M., Clark, A., Walker, J. N., Johnson, P. R., and Rorsman, P. (2010) Gamma-aminobutyric acid (GABA) is an autocrine excitatory transmitter in human pancreatic beta-cells. Diabetes 59, 1694-1701.

25. Dionisio, L., Arias, V., Bouzat, C., and Esandi Mdel, C. (2013) GABAA receptor plasticity in Jurkat T cells. Biochimie 95, 2376-2384.

26. Nakai, T., Nagai, T., Wang, R., Yamada, S., Kuroda, K., Kaibuchi, K., and Yamada, K. (2014) Alterations of GABAergic and dopaminergic systems in mutant mice with disruption of exons 2 and 3 of the Disc 1 gene. Neurochem. Int. 74, 74-83.

27. Gangisetty, O., and Reddy, D. S. (2009) The optimization of TaqMan real-time RT-PCR assay for transcriptional profiling of GABA-A receptor subunit plasticity. J. Neurosci. Methods $181,58-66$.

28. Masocha, W. (2015) Comprehensive analysis of the GABAergic system gene expression profile in the anterior cingulate cortex of mice with Paclitaxel-induced neuropathic pain. Gene Expr. 16, 145-153. 